\title{
Quantifying carbon sequestration potential of soils in an agro-ecological region scale
}

\author{
K. Rajan ${ }^{1, *}$, P. Raja ${ }^{1}$, D. Dinesh ${ }^{2}$, Sanjeev Kumar ${ }^{3}$, B. P. Bhatt ${ }^{3}$, U. Surendran ${ }^{4}$, \\ Deo Karan ${ }^{5}$ and B. P. Bhaskar ${ }^{6}$
}

${ }^{1}$ ICAR-Indian Institute of Soil and Water Conservation, Research Centre, Udhagamandalam 643004 , India

${ }^{2}$ ICAR-Indian Institute of Soil and Water Conservation, Research Centre, Vasad 388 306, India

${ }^{3}$ ICAR Research Complex for the Eastern Region, PO: Bihar Veterinary College, Patna 800 013, India

${ }^{4}$ Centre for Water Resources Development and Management, Calicut 673 571, India

${ }^{5}$ Krishi Vigyan Kendra, ICAR Research Complex for Eastern Region, Buxar 802 103, India

${ }^{6}$ ICAR-National Bureau of Soil Survey and Land Use Planning, Regional Centre, Bengaluru 560 024, India

Soil potential to store organic carbon was assessed in the hot sub-humid dry Agro-Ecological Region (AER) of the Indo-Gangetic Plains under Recent alluvium of southern Bihar, India. The study was carried out in four prevailing cropping systems, viz. Rice-WheatFallow (R-W-F), Pearl millet-Wheat-Fallow (P-WF), pigeon pea (monoculture) and vegetable cultivation. Two different recovery factors were used to estimate Total Organic Carbon (TOC), which yielded similar results. The Soil Organic Carbon (SOC) was found highest in pigeon pea-grown soils (69.2 tonnes $h^{-1}$ ) followed by $R-W-F\left(56.2\right.$ tonnes ha $\left.{ }^{-1}\right)$ and vegetable cultivation $\left(55.8\right.$ tonnes ha $\left.{ }^{-1}\right)$. The lowest SOC stock was found with $\mathrm{P}-\mathrm{W}-\mathrm{F}\left(19.2\right.$ tonnes $\left.\mathrm{ha}^{-1}\right)$. The differences in SOC stock between pigeon pea and that of rice-wheat, vegetables and pearl millet-wheat are 13.0, 13.4 and $50.0 \mathrm{tha}^{-1}$ respectively, that are the quantity of organic carbon can be sequestered further in these three land uses from $47.71,49.12$ and 183.50 tonnes of carbon dioxide from the atmosphere respectively. Highly significant positive correlation of soil qualities parameters such as available nitrogen $\left(r^{2}=0.25\right)$, copper $\left(r^{2}=0.45\right)$, zinc $\left(r^{2}=0.31\right)$ and dehydrogenase activity $\left(r^{2}=0.44\right)$ was found with SOC stock under the hot, sub-humid, dry, AER of southern Bihar. Similar assessment can be done in any AER and the potential of soils can be identified to increase carbon sequestration from the atmosphere.

Keywords: Agro-ecological region, cropping systems, organic carbon stock, recent alluvium, soil quality.

SoIL Organic Carbon (SOC) represents an important pool in the global carbon (C) cycle, with nearly $1307 \mathrm{Pg} \mathrm{C}$ stored in the circumpolar region ${ }^{1}$. This large pool of terrestrial Organic Carbon (OC) is slightly less than twice the amount of $\mathrm{CO}_{2}-\mathrm{C}$ in the atmosphere. Therefore, any change in this carbon reserve as a result of natural or human-induced activities could have a marked effect on the global $\mathrm{C}$ budget. The $\mathrm{C}$ stored in the soil zone appears

\footnotetext{
*For correspondence. (e-mail: krajanars@gmail.com)
}

susceptible to enhanced degradation under the projected conditions of global climate change ${ }^{2-4}$. OC plays a significant role in maintaining physical, chemical and biological quality of the soil. Hence SOC is one of the most important indicators of soil quality ${ }^{5}$. Higher level of OC in the soil sustains higher productivity in any ecosystem. Various ecosystems such as forest, grassland, plantation and agriculture vary in their soil carbon status mainly due to their vegetation and land uses ${ }^{6}$. Land-Use and LandCover (LULC) management causes variation in SOC stocks $^{7}$. An undisturbed forest ecosystem stores highest OC stock due to continuous accumulation of litter compared to other land uses under similar soil and climatic conditions. A major driver of soil $\mathrm{C}$ changes in recent centuries has been LULC. Replacement of natural vegetation with croplands usually leads to soil $\mathrm{C}$ loss, whereas the reverse leads to gain in $\mathrm{SOC}^{8}$. The response of soil $\mathrm{C}$ to LULC depends on the local soil conditions, such as soil type, mineralogy and texture ${ }^{9}$, and on climate influences, such as temperature and soil moisture or precipita$\operatorname{tion}^{10}$. Crop cultivation is a disturbed ecosystem and the OC stock depends on its level of intensive cultivation. Frequent cultivation with intensive tillage supports fast decomposition of stored and applied organic sources, and the carbon stocks tend to be less compared to forest land $^{11}$. The land degradation processes, especially soil erosion, are severely affecting SOC compared to other soil properties $^{12}$. Poeplau and Don ${ }^{13}$ showed that planting cover crops during winter and tilling them into the soil as additional carbon input can significantly enhance soil $\mathrm{C}$ in the croplands.

In India, the OC reserves, either virgin or cultivated, are higher than North America, but lower than those of Central America ${ }^{14}$. They further reported that the observed losses in SOC from managed ecosystems are greater in semiarid environments than in the humid lowlands. Velayutham et $a l .{ }^{15}$ reported that among Indian soils, aridisols contribute $37 \%$ of the total SOC stock, while inceptisols contribute about $22 \%$ of the total SOC stock, vertisols $13 \%$, entisols $7 \%$ and mollisols less than $1 \%$. Bhattacharyya et al. ${ }^{16,17}$ used soil carbon density as a 
tool to prioritize areas for carbon sequestration in different Agro-Ecological Regions (AERs) of India. They ${ }^{16,17}$ further reported that the hot, sub-humid region of southern Bihar, India has maximum reserves of carbon in the soil, which could be due to large areal coverage as well as greater carbon sequestration potential of the soils. Criteria such as SOC stock per unit area as well as point data for individual soils indicate that vast areas in drier parts of the sub-humid Indian subcontinent are low in SOC compared to Soil Inorganic Carbon (SIC) stock. Lal ${ }^{18}$ computed carbon sequestration potential of Indian soils by converting degraded soils into restorative land use, and estimated a total potential of 39-49 (44 \pm 5$) \mathrm{Tg} C$ year $^{-1}$. The estimated SOC pool is $21 \mathrm{Pg}$ in $30 \mathrm{~cm}$ depth and $63 \mathrm{Pg}$ in $150 \mathrm{~cm}$ depth.

The intensive tillage in rice-wheat systems in the North West India is expensive, leading to increase in the cost of production ${ }^{19}$. In addition, farmers remove and/or burn crop residues to facilitate good seedbed preparation leading to low productivity and loss of soil carbon $^{20,21}$, posing a serious threat to the sustainability of the ricebased cropping system ${ }^{22}$. In this study, we present the SOC stock variations under four major cropping systems of an agro-ecological system.

An assessment for SOC density in various land uses with different cropping system explains whether the carbon density has increased or decreased or maintaining over a period. Time-bound assessment of SOC stock in different cropping systems in any AER is essential to improve faulty land-use practices with corrective measures. The hypothesis of the study was that is there any effect of agricultural land uses with different cropping systems on SOC stock in relation to soil properties along with carbon dioxide sequestration potential from the atmosphere. With this background, study was carried out to assess SOC stock in the major cropping systems under the hot, sub-humid, dry AER of southern Bihar.

\section{Materials and methods}

\section{Study area}

The study area of southern Bihar in the Indo-Gangetic Plains cover four AERs $(9,11,12$ and 13). The total geographical area of Bihar is $9.36 \mathrm{~m}$ ha of which $63.5 \%$ area is under AER 13, 31.6\% of area under AER 9 and remaining $4.9 \%$ under AERs 11, 12 and 15 (Figure 1). The area experiences mean annual rainfall of $1000-1250 \mathrm{~mm}$ and potential evapotranspiration of 1300 to $1500 \mathrm{~mm}$.

'Soils of Bihar - their properties and classification', a report published by Dr Rajendra Prasad Central Agricultural University, Pusa, Samstipur, Bihar ${ }^{23}$ was used to identify the recent alluvium under AER 9 in Southern Bihar (Figure 2). Recent alluvium of ustifluvents spreads along the River Ganga from west to east covering three districts, namely Buxar, Bhojpur and Patna with an area of $1685 \mathrm{sq} . \mathrm{km}$. Field survey was conducted and four major cropping systems were identified, viz. (i) RiceWheat-Fallow (R-W-F), (ii) Pearl millet-Wheat-Fallow (P-W-F), (iii) pigeon pea (monoculture) and (iv) Vegetable cultivation. A brief description of each cropping system is given below.

Rice-Wheat-Fallow $(R-W-F)$ system: This is the traditional system in lowlands with limited use of organics and the crop residues left in the field are burnt after harvest. The chemical fertilizers used include urea as a nitrogenous fertilizer, di-ammonium phosphate/single super phosphate (DAP/SSP) as a phosphatic fertilizer and rarely any potassic fertilizer. The commonly grown rice varieties are MTU 7029, Gautam, Mansuri, Satyam, Kishori, Raj Shree, Pankaj, Swarnadhan, while wheat varieties include HUW 234, PBW 154, HD 2733 and HD 2824. The recommended dose of NPK for rice and wheat is $100: 60: 50 \mathrm{~kg} / \mathrm{ha}$. Farmers apply approximately $185 \mathrm{~kg}$ of $\mathrm{N}$ and $25 \mathrm{~kg}$ of $\mathrm{P}$ as urea and DAP/SSP respectively. At the time of sowing/transplanting (both rice and wheat), farmers apply DAP and thereafter urea in two equal splits. Rice is grown during kharif as rainfed with limited irrigation using canal water and wheat during rabi with 2-3 irrigations.

Pearl millet-Wheat-Fallow $(P-W-F)$ system: This system is prevalent in marginal uplands under rainfed conditions. The common pearl millet hybrids are PHB 10 and MH 143 as well as some local varieties. The recommended dose of fertilizers is $90: 50: 50 \mathrm{~kg} / \mathrm{ha}$ of NPK for pearl millet and $100: 60: 50 \mathrm{~kg} / \mathrm{ha}$ for wheat. It was observed that less quantity of fertilizer applied; $75-80 \%$ of pearl millet was used as fodder and $20-25 \%$ for grain purpose. About $40 \%$ of wheat is generally sown by zero-tillage machine and rest manually with $2-3$ irrigations.

Pigeon pea (monoculture): Pigeon pea is one of the profitable crops grown on medium textured alluvial soil. It is cultivated during June to November every year and rest of the period will be fallow. Major varieties are Narendra Arhar 2, Malviya 13, UPAS 120 and Pusa 9 with $25: 50: 50 \mathrm{~kg}$ of NPK applied per hectare. The duration is around 170-180 days, except UPAS 120.

Vegetable cultivation: Commercial cultivation of vegetables is done under irrigated tracts with high doses of manure and fertilizer. Among vegetables, tomato (Solanum lycopersicum), brinjal (Solanum melongena), okra (Abelmoschus esculentus), chillies (Capsicum annuum), cauliflower (Brassica oleracea var. botrytis), cabbage (Brassica oleracea var. capitata), carrot (Daucus carota) and beetroot (Beta vulgaris) are grown. Creeper vegetables such 


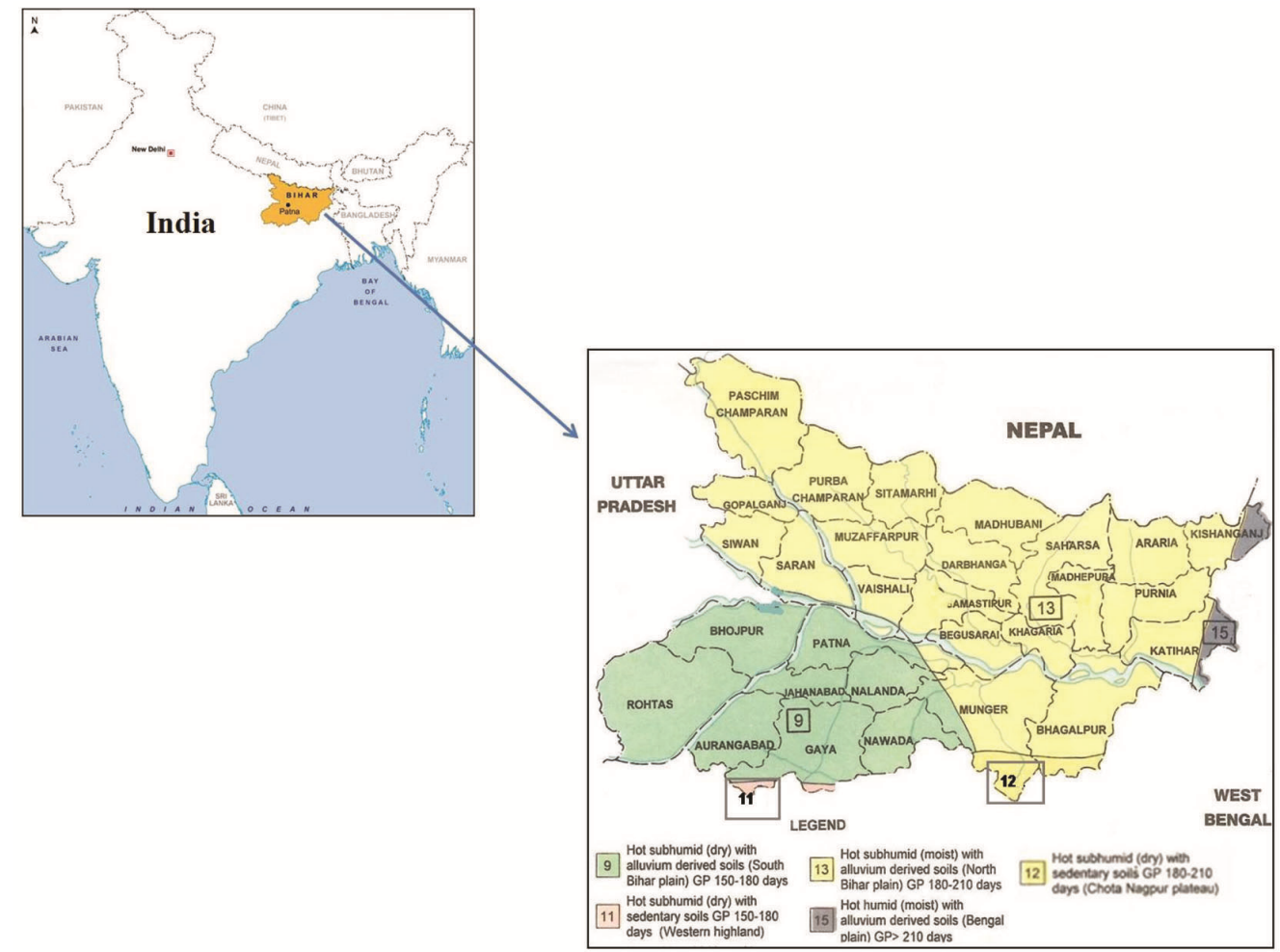

Figure 1. Location map and Agro-Ecological Regions (AERs) of Bihar, India.

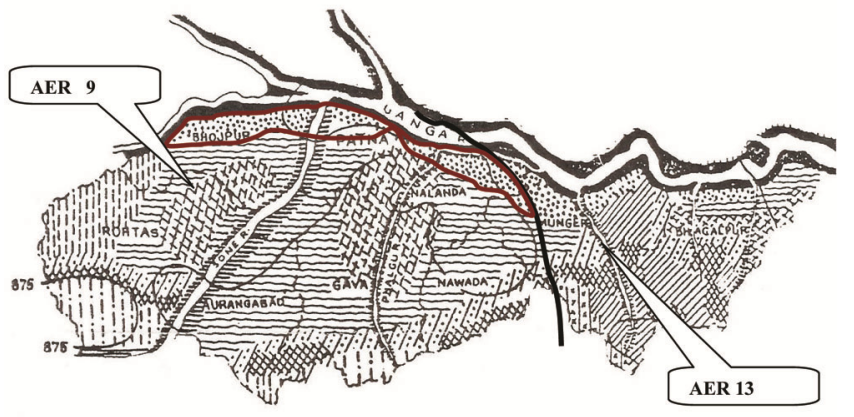

Recent alluvium (non calcareous and non-saline)

Figure 2. Recent alluvium of AER-9 in South Bihar.

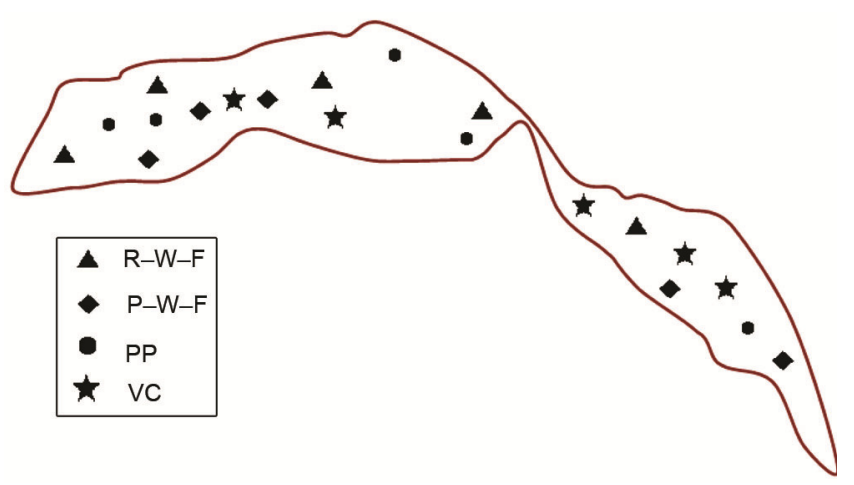

Figure 3. Location of profile samples of four major cropping systems under recent alluvium. R-W-F: Rice-Wheat-Fallow system; P-W-F, Pearl millet-Wheat-Fallow system; PP, Pigeon pea monoculture; VC, Vegetable cultivation. as bottle gourd (Lagenaria siceraria), bitter gourd (Momordica charantia), sponge gourd (Luffa aegyptiaca) and ribbed gourds (Luffa aegyptiaca) are grown during rainy season on iron wires or net using bamboo poles, while during summer these are grown on the surface. In some areas, creepers and maize are intercropped and thus there is no need of stacking or wiring for the creepers. Farmers use recommended plant protection measures to protect the crops from insect-pests and diseases.

\section{Soil sampling and analysis}

Sampling sites were selected based on land-use history as collected from interviews conducted with the local farmers. Five sites each were selected for the four cropping systems representing the entire study area (Figure 3 ). Soil samples were collected up to $60 \mathrm{~cm}$ depth from the surface with $15 \mathrm{~cm}$ increment, as this part of soil is disturbed by agricultural practices and plays an important role in carbon sequestration ${ }^{24}$. Soil bulk density and SOC were measured for four separate depths with $15 \mathrm{~cm}$ increments.

For the estimation of bulk density, undisturbed soil core samples were collected separately for each soil depth $^{25}$. Rock fragments more than $2 \mathrm{~mm}$ size were removed from the core samples. The weight and volume of the rock fragments were estimated which were deducted from the weight and volume of soil core. Soil samples were air-dried and passed through $0.5 \mathrm{~mm}$ sieve. This fraction of the sample was used for estimation of 
SOC through wet oxidation method ${ }^{26}$. This method estimates $77 \%$ of $\mathrm{OC}$ and a recovery factor of 1.29 was used as the Walkley and Black recovery factor (WBRF) for estimation of TOC. Another recovery factor determined by Bhattacharya et $a l .^{27}$ was used to estimate TOC; both the methods were compared. Recovery factor determined by Bhattacharya et al. ${ }^{27}$ is mainly for the IndoGangetic Plains, especially in the study area of the sub-humid region. According to the authors ${ }^{27}$, the recovery percentage decreases with increasing depth of soil. It is $81 \%$ (recovery factor of 1.23 ) for $0-30 \mathrm{~cm}, 70 \%$ (recovery factor of 1.43 ) for $30-50 \mathrm{~cm}$ and $46 \%$ (recovery factor of 1.57) for $50-100 \mathrm{~cm}$ soil depth to obtain TOC. Soil available nitrogen was estimated with alkali permanganate method $^{28}$, DTPA extractable copper and zinc were estimated according to method outlined by Lindsay and Norvell $^{29}$ and dehydrogenase activity by the method of Casida et $a l .{ }^{30}$.

\section{Soil organic carbon stock estimation}

SOC stock $\left(\mathrm{kg} \mathrm{m}^{-2}\right)$ was estimated from per cent $\mathrm{OC}$, bulk density and depth according to the following formula ${ }^{31}$

$$
\text { SOC stock }=\frac{\left(\begin{array}{c}
L_{1} \times \mathrm{SOC} P_{1} \times \rho 33_{1} x\left(1-V>2_{1}\right) / \\
100+L_{2} \times \mathrm{SOC} P_{2} \times \rho 33_{2} \\
\left(1-V>2_{2}\right) / 100+\ldots
\end{array}\right)}{10},
$$

where SOC is the soil organic carbon $\left(\mathrm{kg} \mathrm{m}^{-2}\right)$ soil; SOC $P_{1}$, SOC $P_{2} \ldots$ the SOC per cent of different horizons $1,2, \ldots, n$ in order from surface to the bottom; $L_{1}, L_{2}, \ldots$, the thickness of different horizons $1,2, \ldots, n$ in order from surface to bottom; $\rho 33_{1}, \rho 33_{2}, \ldots$, the bulk density of $<2 \mathrm{~mm}$ fraction of the core samples of horizons 1 , $2, \ldots, n . V>2_{1}, V>2_{2}, \ldots$, the volume per cent of $>2 \mathrm{~mm}$ fraction of core samples of horizons $1,2, \ldots, n$. Where $\rho$ is the bulk density and here is the corrected bulk density $\left(\mathrm{Mg} \mathrm{m}^{-3}\right)$ after removing coarse fractions $>2 \mathrm{~mm}$ size in soil including plant debris. The corrected bulk density is estimated as follows.

$$
\rho=\frac{\text { Mass }_{\text {sample }}-\text { Mass }_{\text {rock fragments }}}{\text { Volume }_{\text {sample }}-\left(\text { Mass }_{\text {rock fragments }} / \rho_{\text {rock fragments }}\right)} .
$$

\section{Estimation of carbon dioxide from soil carbon sequestration}

The mass of $\mathrm{CO}_{2}$ sequestered from the atmosphere is greater than the mass of carbon $(\mathrm{C})$ alone, because $\mathrm{C}$ is stored and oxygen $\left(\mathrm{O}_{2}\right)$ is re-emitted into the atmosphere. The atomic mass of $\mathrm{C}$ is 12 and the molecular mass of $\mathrm{CO}_{2}$ is 44 . Therefore, for every 12 metric tonnes of $\mathrm{C}$ stored, 44 metric tonnes of $\mathrm{CO}_{2}$ has been sequestered. The conversion factor from $\mathrm{C}$ to $\mathrm{CO}_{2}$ is $44 / 12=3.67$.

Hence the conversion factor of carbon to carbon dioxide is 3.67 , i.e. 1 tonne of OC sequestered in the soil is equivalent to 3.67 tonnes of $\mathrm{CO}_{2}$ from the atmosphere ${ }^{32}$.

\section{Statistical analysis}

Descriptive statistics on SOC and bulk density, and correlation analysis between SOC stocks and soil quality indicators was carried out using Microsoft XLSTAT.

\section{Results and discussion}

\section{Variation in soil properties}

Soil texture was clay loam in $\mathrm{R}-\mathrm{W}-\mathrm{F}$, pigeon pea and vegetable-growing soils (Table 1 ). The $\mathrm{P}-\mathrm{W}-\mathrm{F}$ system is being followed in upland areas mainly rainfed with limited irrigation through bore wells. The soil is sandy clay loam, which is light-textured compared to clay loam. Soils in the study area were non-saline-alkali and Electric Conductivity (EC) ranged from 0.09 to $0.24 \mathrm{dS} \mathrm{m}^{-1}$. Higher EC was observed in vegetable cultivation, where intensive cultivation is practiced with high water and nutrient inputs. Soil reaction was neutral to alkaline and ranged from 6.8 to 8.5 . Available nitrogen ranged from 111.8 to $232.0 \mathrm{~kg} \mathrm{ha}^{-1}$, which falls in low to medium range of rating. Low nitrogen was observed in the sub soil layers. Available phosphorus ranged from 2.7 to $26.9 \mathrm{~kg} \mathrm{ha}^{-1}$ and the highest quantity was observed in vegetable cultivation. Majority of the soils ranged from low to medium range, except surface soil of vegetable cultivation. Available potassium was in low to medium range. Both copper and zinc were in sufficient levels, except in subsurface soils under $\mathrm{P}-\mathrm{W}-\mathrm{F}$ system. Dehydrogenase activity ranged from 1.8 to $76.6 \mu \mathrm{g}$ of TPF activity $\mathrm{g}^{-1}$ day $^{-1}$ and the highest activity was observed in pigeon pea-grown soil.

\section{Soil organic carbon}

SOC content ranged from $0.33 \%$ to $0.73 \%$ in $\mathrm{R}-\mathrm{W}-\mathrm{F}$ system, $0.08 \%$ to $0.29 \%$ in $\mathrm{P}-\mathrm{W}-\mathrm{F}$ system, $0.46 \%$ to $0.81 \%$ in pigeon pea-grown soil and $0.11 \%$ to $0.82 \%$ in vegetable-growing soils (Table 2). OC content was higher in the surface layers and decreased with increasing depth in all the cropping systems. TOC content was estimated using recovery factors of Walkley and $\mathrm{Black}^{26}$, and Bhattacharya et al. ${ }^{27}$. Though there were some differences in the carbon content in the soil profile, it was observed that there was no significant difference between the two recovery factors. OC content of both the estimations was analysed using Student $t$ test. The test statistics values 
Table 1. Properties of soils under different cropping systems in recent alluvium

\begin{tabular}{|c|c|c|c|c|c|c|c|c|c|}
\hline $\begin{array}{l}\text { Depth } \\
(\mathrm{cm})\end{array}$ & Soil texture & 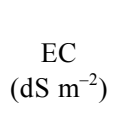 & $\mathrm{pH}$ & $\begin{array}{c}\text { Available N } \\
\left(\mathrm{kg} \mathrm{ha}^{-1}\right)\end{array}$ & $\begin{array}{c}\text { Available P } \\
\left(\mathrm{kg} \mathrm{ha}^{-1}\right)\end{array}$ & $\begin{array}{l}\text { Available K } \\
\left(\mathrm{kg} \mathrm{ha}^{-1}\right)\end{array}$ & $\begin{array}{l}\text { Available } \mathrm{Cu} \\
\quad\left(\mathrm{mg} \mathrm{kg}^{-1}\right)\end{array}$ & $\begin{array}{l}\text { Available } \mathrm{Zn} \\
\quad\left(\mathrm{mg} \mathrm{kg}^{-1}\right)\end{array}$ & $\begin{array}{c}\text { Dehydrogenase activity } \\
(\mu \mathrm{g} \text { of TPF activity } \\
\left.\mathrm{g}^{-1} \text { day }^{-1}\right)\end{array}$ \\
\hline \multicolumn{10}{|l|}{$\mathrm{R}-\mathrm{W}-\mathrm{F}$} \\
\hline $0-15$ & Clay loam & 0.21 & 7.6 & 184.7 & 17.1 & 256.02 & 2.1 & 0.7 & 61.6 \\
\hline $15-30$ & Clay loam & 0.17 & 8.3 & 167.6 & 9.3 & 193.2 & 1.4 & 0.7 & 18.3 \\
\hline $30-45$ & Clay loam & 0.13 & 8.5 & 122.3 & 11.7 & 192.5 & 1.1 & 0.5 & 12.4 \\
\hline $45-60$ & Clay loam & 0.12 & 8.1 & 113.2 & 8.7 & 174.6 & 1.4 & 0.7 & 3.8 \\
\hline Mean & - & 0.16 & 8.13 & 146.95 & 5.95 & 204.08 & 1.50 & 0.65 & 24.03 \\
\hline $\mathrm{SD}$ & - & 0.04 & 0.39 & 34.63 & 7.47 & 35.67 & 0.42 & 0.10 & 25.75 \\
\hline \multicolumn{10}{|l|}{$\mathrm{P}-\mathrm{W}-\mathrm{F}$} \\
\hline $0-15$ & Sandy clay loam & 0.14 & 7.3 & 175.2 & 14.2 & 416.2 & 1.9 & 0.2 & 24.0 \\
\hline $15-30$ & Sandy clay loam & 0.13 & 7.9 & 143.7 & 4.7 & 308.7 & 1.3 & 0.7 & 4.1 \\
\hline $30-45$ & Sandy clay loam & 0.14 & 8.3 & 129.8 & 3.5 & 315.7 & 1.2 & 0.4 & 2.9 \\
\hline $45-60$ & Sandy clay loam & 0.09 & 8.1 & 115.9 & 2.7 & 277.4 & 1.2 & 0.3 & 1.8 \\
\hline Mean & & 0.13 & 7.90 & 141.15 & 6.28 & 329.50 & 1.15 & 0.40 & 8.20 \\
\hline SD & & 0.02 & 0.43 & 25.38 & 5.35 & 60.15 & 0.17 & 0.22 & 10.58 \\
\hline \multicolumn{10}{|l|}{ PP } \\
\hline $0-15$ & Clay loam & 0.12 & 6.8 & 180.7 & 8.6 & 123.7 & 1.6 & 2.5 & 76.6 \\
\hline $15-30$ & Clay loam & 0.13 & 7.8 & 171.5 & 5.6 & 77.3 & 1.1 & 0.5 & 31.2 \\
\hline $30-45$ & Clay loam & 0.11 & 8.2 & 157.8 & 1.2 & 72.4 & 1.2 & 0.9 & 18.7 \\
\hline $45-60$ & Clay loam & 0.11 & 8.5 & 111.8 & 1.0 & 68.9 & 1.3 & 0.8 & 11.3 \\
\hline Mean & & 0.12 & 7.83 & 155.45 & 4.10 & 85.58 & 1.05 & 1.18 & 34.45 \\
\hline SD & & 0.01 & 0.74 & 30.58 & 3.68 & 25.65 & 0.31 & 0.90 & 29.28 \\
\hline \multicolumn{10}{|l|}{$\mathrm{VC}$} \\
\hline $0-15$ & Clay loam & 0.24 & 7.4 & 232.0 & 26.9 & 311.0 & 2.3 & 2.5 & 32.6 \\
\hline $15-30$ & Clay loam & 0.21 & 8.4 & 173.8 & 12.8 & 216.7 & 2.7 & 1.4 & 10.5 \\
\hline $30-45$ & Clay loam & 0.18 & 8.1 & 173.8 & 8.9 & 152.0 & 1.9 & 0.1 & 9.3 \\
\hline $45-60$ & Clay loam & 0.15 & 8.4 & 125.1 & 3.8 & 153.3 & 1.4 & 0.8 & 3.2 \\
\hline Mean & & 0.20 & 8.08 & 176.18 & 13.10 & 208.25 & 2.08 & 1.20 & 13.90 \\
\hline SD & & 0.04 & 0.47 & 43.73 & 9.91 & 74.86 & 0.56 & 1.02 & 12.87 \\
\hline
\end{tabular}

R-W-F, Rice-Wheat-Fallow; P-W-F, Pearl millet-Wheat-Fallow; PP, Pigeon Pea; VC, Vegetable Cultivation. SD( \pm ), Standard Deviation.

Table 2. Depthwise Soil Organic Carbon (SOC) content and Bulk Density (BD) in the profile of major cropping systems in recent alluvium

\begin{tabular}{|c|c|c|c|c|c|c|c|c|}
\hline \multirow[b]{2}{*}{ Soil depth $(\mathrm{cm})$} & \multicolumn{4}{|c|}{ SOC (\%) } & \multicolumn{4}{|c|}{$\mathrm{BD}\left(\mathrm{Mg} \mathrm{m}^{-3}\right)$} \\
\hline & $\mathrm{R}-\mathrm{W}-\mathrm{F}$ & $\mathrm{P}-\mathrm{W}-\mathrm{F}$ & $\mathrm{PP}$ & $\mathrm{VC}$ & $\mathrm{R}-\mathrm{W}-\mathrm{F}$ & $\mathrm{P}-\mathrm{W}-\mathrm{F}$ & PP & $\mathrm{VC}$ \\
\hline $0-15$ & $0.73 \pm 0.15$ & $0.29 \pm 0.06$ & $0.81 \pm 0.08$ & $0.82 \pm 0.15$ & $1.55 \pm 0.26$ & $1.55 \pm 0.35$ & $1.31 \pm 0.15$ & $1.54 \pm 0.18$ \\
\hline $15-30$ & $0.55 \pm 0.09$ & $0.20 \pm 0.03$ & $0.78 \pm 0.09$ & $0.69 \pm 0.06$ & $1.40 \pm 0.19$ & $1.42 \pm 0.28$ & $1.40 \pm 0.13$ & $1.44 \pm 0.26$ \\
\hline $30-45$ & $0.46 \pm 0.08$ & $0.11 \pm 0.02$ & $0.56 \pm 0.05$ & $0.40 \pm 0.04$ & $1.48 \pm 0.24$ & $1.38 \pm 0.24$ & $1.46 \pm 0.13$ & $1.39 \pm 0.12$ \\
\hline $45-60$ & $0.33 \pm 0.06$ & $0.08 \pm 0.02$ & $0.46 \pm 0.04$ & $0.11 \pm 0.01$ & $1.51 \pm 0.34$ & $1.41 \pm 0.29$ & $1.41 \pm 0.17$ & $1.38 \pm 0.13$ \\
\hline
\end{tabular}

R-W-F, Rice-Wheat-Fallow; P-W-F, Pearl millet-Wheat-Fallow; PP, Pigeon Pea; VC, Vegetable Cultivation.

were insignificant, because TOC estimated using WBRF and the recovery factor of Bhattacharya et $a l^{27}$ was $<1.0$. Hence TOC estimated using the recovery factor of Bhattacharya et al..$^{27}$ was taken for calculations, which has the benefit of depthwise estimation. Among the four cropping systems, TOC ranged from $0.47 \%$ to $0.90 \%$ in $\mathrm{R}-\mathrm{W}-\mathrm{F}$ system, $0.11 \%$ to $0.36 \%$ in $\mathrm{P}-\mathrm{W}-\mathrm{F}$ system, $0.66 \%$ to $1.01 \%$ in pigeon pea-grown soil and $0.16 \%$ to $1.01 \%$ in vegetable-growing soil (Table 3 ).

The highest mean TOC was observed in pigeon peagrown soils $(0.85 \%)$, which was 3.9 times higher than the $\mathrm{P}-\mathrm{W}-\mathrm{F}$ system $(0.22 \%)$. Higher storage of $\mathrm{OC}$ in pigeon pea-grown soil is due to its long crop duration $(>180$ days) with deep root system compared to other annual crops. The surface layers had high OC content with gradational decreasing trends with depth; however, the decrease was marginal due to more carbon storage in subsoil by pigeon pea $(\mathrm{SD}=0.17)$ compared to vegetablegrowing soil $(\mathrm{SD}=0.32)$. The surface enrichment of $\mathrm{OC}$ in soils has been attributed to litter accumulation and decomposition, addition of manures and higher root activity $^{33}$.

The second highest TOC after pigeon pea, was observed in the $\mathrm{R}-\mathrm{W}-\mathrm{F}$ system with the profile mean of $0.68 \%$. This system stored reasonable quantity of $\mathrm{OC}$ compared to vegetable cultivation and the $\mathrm{P}-\mathrm{W}-\mathrm{F}$ system. The $\mathrm{OC}$ stored in the system was three times higher than $\mathrm{P}-\mathrm{W}-\mathrm{F}$ system. TOC in the profile showed a 
Table 3. Total SOC under major cropping systems with two recovery factors (RFs) in recent alluvium

\begin{tabular}{|c|c|c|c|c|c|c|c|c|}
\hline \multirow[b]{2}{*}{ Soil depth $(\mathrm{cm})$} & \multicolumn{4}{|c|}{$\begin{array}{c}\text { Total SOC (\%) with } \\
\text { RF of } 77 \% \text { by Walkley and Black }{ }^{26}\end{array}$} & \multicolumn{4}{|c|}{$\begin{array}{c}\text { Total SOC }(\%) \text { with } \\
\text { RF by Bhattacharya et al. }{ }^{27}\end{array}$} \\
\hline & $\mathrm{R}-\mathrm{W}-\mathrm{F}$ & $\mathrm{P}-\mathrm{W}-\mathrm{F}$ & PP & $\mathrm{VC}$ & $\mathrm{R}-\mathrm{W}-\mathrm{F}$ & $\mathrm{P}-\mathrm{W}-\mathrm{F}$ & PP & $\mathrm{VC}$ \\
\hline $0-15$ & 0.95 & 0.38 & 1.05 & 1.06 & 0.90 & 0.36 & 1.00 & 1.01 \\
\hline $15-30$ & 0.71 & 0.26 & 1.01 & 0.90 & 0.68 & 0.25 & 0.96 & 0.85 \\
\hline $30-45$ & 0.60 & 0.14 & 0.73 & 0.52 & 0.66 & 0.16 & 0.80 & 0.57 \\
\hline $45-60$ & 0.43 & 0.10 & 0.60 & 0.14 & 0.47 & 0.11 & 0.66 & 0.16 \\
\hline Mean & 0.67 & 0.22 & 0.85 & 0.66 & 0.68 & 0.22 & 0.85 & 0.65 \\
\hline
\end{tabular}

Table 4. Distribution of SOC stock under major cropping systems with two RFs in recent alluvium

\begin{tabular}{|c|c|c|c|c|c|c|c|c|}
\hline \multirow[b]{2}{*}{ Soil depth (cm) } & \multicolumn{4}{|c|}{$\begin{array}{c}\text { SOC stock }\left(\mathrm{kg} \mathrm{m}^{-2}\right) \text { based on } \\
\text { Walkley and Black }\end{array}$} & \multicolumn{4}{|c|}{$\begin{array}{c}\text { SOC stock }\left(\mathrm{kg} \mathrm{m}^{-2}\right) \text { based on } \\
\text { Bhattacharya et al. }{ }^{27}\end{array}$} \\
\hline & $\mathrm{R}-\mathrm{W}-\mathrm{F}$ & $\mathrm{P}-\mathrm{W}-\mathrm{F}$ & PP & $\mathrm{VC}$ & $\mathrm{R}-\mathrm{W}-\mathrm{F}$ & $\mathrm{P}-\mathrm{W}-\mathrm{F}$ & PP & $\mathrm{VC}$ \\
\hline $0-15$ & 2.20 & 0.86 & 2.10 & 2.48 & 2.09 & 0.82 & 1.99 & 2.34 \\
\hline $15-30$ & 1.50 & 0.55 & 2.17 & 1.96 & 1.42 & 0.52 & 2.06 & 1.86 \\
\hline $30-45$ & 1.36 & 0.31 & 1.63 & 1.11 & 1.50 & 0.34 & 1.79 & 1.23 \\
\hline $45-60$ & 0.97 & 0.22 & 1.27 & 0.30 & 1.07 & 0.24 & 1.40 & 0.33 \\
\hline Total & 6.04 & 1.94 & 7.17 & 5.85 & 6.08 & 1.92 & 7.24 & 5.76 \\
\hline
\end{tabular}

decreasing trend with standard deviation of 0.71 . Rice crop is mostly grown in clayey soil. Though it is an intensive cultivation, $\mathrm{OC}$ storage in the stable aggregates due to heavy clay content might be the reason for higher TOC in the R-W-F system. Vegetable cultivation too stored higher amounts of TOC compared to the $\mathrm{P}-\mathrm{W}-\mathrm{F}$ system. It is an intensive cultivation with heavy inputs of manure and fertilizers. Cultivation of potato, beetroot, carrot and other vegetables needs heavy manuring and fertilizers which accumulate more nutrients and OC in the surface layer. The TOC content decreased with depth with highest standard deviation of 0.32 among all the cropping systems in the study region. OC storage in vegetable cultivation was similar to that of the $\mathrm{R}-\mathrm{W}-\mathrm{F}$ system, which was three times higher than the $\mathrm{P}-\mathrm{W}-\mathrm{F}$ system. The lowest TOC was recorded in the $\mathrm{P}-\mathrm{W}-\mathrm{F}$ system. The low standard deviation in the vertical distribution of $\mathrm{OC}$ in $\mathrm{P}-\mathrm{W}-\mathrm{F}$ system was due to low input application in this marginal upland cultivation and higher decomposition rate of OC. The difference of OC in the surface and subsurface soils was meagre.

\section{Soil bulk density}

The mean bulk density ranged from 1.42 to $1.50 \mathrm{Mg} \mathrm{m}^{-3}$ under different cropping systems in the study area (Table 2 ). The bulk density was more in R-W-F system compared to vegetable cultivation and $\mathrm{P}-\mathrm{W}-\mathrm{F}$ system. The lowest bulk density was observed in pigeon peagrown soils. Bulk density in the $\mathrm{R}-\mathrm{W}-\mathrm{F}$ system was similar from the surface $(0-15 \mathrm{~cm})$ to subsurface layers $(15-60 \mathrm{~cm})$. Wet ploughing for rice cultivation might be the reason for high bulk density in the surface and sub- surface soil layers ${ }^{34}$. The $\mathrm{P}-\mathrm{W}-\mathrm{F}$ system and vegetable cultivation with moderately intensive tillage had high bulk density in the surface layers, which decreased with increasing depth. Lowest bulk density was observed in pigeon pea-grown soils and the density increased with increasing depth. Pigeon pea is cultivated once in a year and in the remaining period the land is kept fallow. Hence the soil maintains low bulk density compared to other cropping systems and the accumulation of litter on the surface with less tillage might have maintained low bulk density in the surface layer of the soil ${ }^{35}$.

\section{Soil organic carbon stock and equivalent carbon dioxide}

SOC stock ranged from 1.92 to $7.24 \mathrm{~kg} \mathrm{~m}^{-2}$ up to $60 \mathrm{~cm}$ depth among different cropping systems (Table 4). It was highest in pigeon pea-grown soils. Decreased soil disturbance increases SOC and improves soil quality ${ }^{36}$. Pigeon pea is a leguminous and sturdy crop which produces more litter than other cropping system. Weber et al. ${ }^{37}$ observed that introduction of legume under no-tillage improved the soil carbon status and the highest potential of carbon stock was observed in pigeon pea-grown soils. The $\mathrm{R}-\mathrm{W}-\mathrm{F}$ system and vegetable cultivation maintained similar amounts of SOC stock. Intensive tillage and high input use in vegetable cultivation might be the reason for higher level of SOC stock. R-W-F system sequestered higher SOC stock than vegetable cultivation. The $\mathrm{P}-\mathrm{W}-\mathrm{F}$ system is cultivated in light textured marginal upland under rainfed condition with low input use. There is corroborative evidence from the results of an earlier study that carbon loss is more in light textured soils ${ }^{38}$. Pigeon 


\section{RESEARCH ARTICLES}

pea-grown soils recorded the highest OC stock in the recent alluvium of AER 9.2, which is 3.6-fold higher that of the $\mathrm{P}-\mathrm{W}-\mathrm{F}$ system. Soils under the $\mathrm{R}-\mathrm{W}-\mathrm{F}$ system and vegetable cultivation showed 2.9-fold higher SOC stock than the $\mathrm{P}-\mathrm{W}-\mathrm{F}$ system. Quantitatively, the pigeon peagrown soils stored/sequestered 69.2 tonnes ha ${ }^{-1}$ which is highest among the cropping system in the region. $\mathrm{R}-\mathrm{W}-\mathrm{F}$ system sequestered 56.2 tonnes $\mathrm{ha}^{-1}$ of SOC stock and still has the potential to sequester 13.0 tonnes of OC further to the level of pigeon pea grown soil that is equivalent to 47.71 tonnes of $\mathrm{CO}_{2}$ gas in the atmosphere. Vegetable cultivation has the potential to sequester 13.4 tonnes $\mathrm{ha}^{-1}$ of $\mathrm{OC}$ further which is equivalent to 49.12 tonnes of $\mathrm{CO}_{2}$ gas in the atmosphere. Highest carbon sequestration potential was found in the $\mathrm{P}-\mathrm{W}-\mathrm{F}$ system for 50.0 tonnes $\mathrm{ha}^{-1}$ of $\mathrm{OC}$, which is equivalent to 183.50 tonnes of $\mathrm{CO}_{2}$ in the atmosphere. Crop residue management with conservation tillage can increase the carbon stock ${ }^{39}$ instead of burning crop residues and practising conventional tillage in the region.

\section{Relationship between soil organic carbon stock and soil qualities}

OC density positively influences soil quality indicators such as available nitrogen, copper, zinc and dehydrogenase activity. Soil available nitrogen was found to have highly positive significant correlation with OC stock $\left(r^{2}=0.25\right)$. Soil nitrogen is part of organic matter; when it is decomposed, nitrogen is released into the soil. A positive linear relationship was observed in that soil organic carbon increases with increase in nitrogen content ${ }^{40}$, indicating the proportional accumulation of available nitrogen. Micronutrients such as copper $\left(r^{2}=0.45\right)$ and zinc $\left(r^{2}=0.31\right)$ were significantly and positively correlated with $\mathrm{SOC}^{41-43}$. Meena and Mathur ${ }^{44}$ reported that zinc content increases with increasing SOC because of its chelating effect. Soil dehydrogenase activity was observed to have a highly positive significant relationship with OC stock in the recent alluvium $\left(r^{2}=0.44\right)$. SOC is a food source for microbes and its higher content increases the dehydrogenase activities. Cropping system with varied levels of SOC stocks had significantly positive correlation with dehydrogenase activity. More SOC supports more microbial activity as indicated by dehydrogenase activity ${ }^{45}$.

\section{Conclusion}

Land uses and cropping systems influence soil quality and OC storage at varied levels. Cropping systems under agricultural land use induced variations in SOC stocks. Two recovery factors were used to estimate TOC, we found that there was no difference between these two factors; hence, any one method can be used. Recent alluvium under the hot, sub-humid, dry, region of Indo-Gangetic plains recorded high OC stock in pigeon pea-grown soils, because it is long-duration leguminous crop with more leaf litter accumulation and less disturbance to the soil ecosystem, followed by the R-W-F system and vegetable cultivation. Carbon sink capacity in terms of OC storage capacity was found highest in pigeon pea-grown soils (69.2 tonnes $\left.\mathrm{ha}^{-1}\right)$. The $\mathrm{R}-\mathrm{W}-\mathrm{F}$ system and vegetable cultivation also had reasonably high OC stock. These two land-use systems have more potential for carbon sequestration. Highest potential of carbon sequestration in the form of SOC was found in the $\mathrm{P}-\mathrm{W}-\mathrm{F}$ system with 50.0 tonnes $\mathrm{ha}^{-1}$, which is equivalent to 183.5 tonnes of $\mathrm{CO}_{2}$ in the atmosphere. Introducing pigeon pea in other cropping systems in the region will improve the OC stock of soil. Green manure cultivation during fallow season, crop residues, cattle manure application and application of biochar from crop residues with conservation tillage will improve SOC stock in the R-W-F system vegetable cultivation and $\mathrm{P}-\mathrm{W}-\mathrm{F}$ system under hot, sub-humid, dry AER of the Indo-Gangetic plains and the regions of recent alluvium.

1. Hugelius, G., Strauss, J., Zubrzycki, S., Harden, J. W., Schuur, E. A. G. and Ping, C. L., Estimated stocks of circumpolar permafrost carbon with quantified uncertainty ranges and identified data gaps. Biogeosciences, 2014, 11, 6573-6593.

2. Lindroth, A., Grelle, A. and Móren, A. S., Long-term measurements of boreal forest carbon balance reveal large temperature sensitivity. Global Change Biol., 1998, 4, 443-450.

3. Sjögersten, S. and Wookey, P. A., The impact of climate change on ecosystem carbon dynamics at the Scandinavian mountain birch forest - Tundra Heath Ecotone. Ambio, 2009, 38, 1-1.

4. Jungqvist, G., Oni, S. K., Teutschbein, C. and Futter, M. N., Effects of climate change on soil temperature in Swedish boreal forests. PLoS ONE, 2014, 9, e93957.

5. Wang, J., Fu, B., Qiu, Y. and Chen, L., Analysis on soil nutrient characteristics for sustainable land use in Danangou catchment of the Loess Plateau, China, Catena, 2003, 54, 17-29.

6. Awasthi, K. D., Singh, B. R. and Sitaula, B. K., Profile carbon and nutrient levels and management effect on soil quality indicators in the Mardi watershed of Nepal. Acta Agricul. Scand., Sect. B, 1986, 55, 192-204.

7. Ollinger, S. V., Smith, M. L., Martin, M. E., Hallett, R. A., Goodale, C. L. and Aber, J. D., Regional variation in foliar chemistry and $\mathrm{N}$ cycling among forests of diverse history and composition. Ecology, 2002, 83, 339-355.

8. Guo, L. B. and Gifford, M., Soil carbon stocks and land use change: a meta analysis. Global Change Boil., 2002, 8, 345-360.

9. Lugo, E. A., Sanchez, J. M. and Brown, S., Land use and organic carbon content of some subtropical soils. Plant Soil, 1986, 96, 185-196.

10. Marín-Spiotta, E. and Sharma, S., Carbon storage in successional and plantation forest soils: a tropical analysis. Global Ecol. Biogeogr., 2013, 22, 105-117.

11. Krishnan, P. et al., Organic carbon stock map for soils of South India: a multifactorial approach. Curr. Sci., 2007, 93, 706-710.

12. Rajan, K., Natarajan, A., Anil Kumar, K. S., Badrinath, M. S. and Gowda, R. C., Soil organic carbon - a most reliable soil quality indicator for monitoring land degradation by soil erosion. Curr. Sci., 2010, 99, 823-827. 
13. Poeplau, C. and Don, A., Sensitivity of soil organic carbon stocks and fractions to different land-use changes across Europe. Geoderma, 2013, 192, 189-201.

14. Jenny, H. and Raychaudhuri, S. P., Effect of climate and cultivation on nitrogen and organic matter reserves in Indian soils. Indian Council of Agricultural Research, New Delhi, 1960.

15. Velayutham, M., Pal, D. K. and Bhattacharyya, T., Organic carbon stock in soils of India. In Global Climate Change and Tropical Ecosystems (eds Lal, R., Kimble, J. M. and Stewart, B. A.), Lewis Publishers, FL, USA, 2000, pp. 71-95.

16. Bhattacharyya, T., Pal, D., Chandran, P., Mandal, C., Ray, S. K., Gupta, R. K. and Gajbhiye, K. S., Managing soil carbon stocks in the Indo-Gangetic Plains, India. Rice-Wheat Consortium for the Indo-Gangetic Plains, New Delhi, 2004, p. 44; http://www. rwccgiar.org and http://www.cimmyt.org.

17. Bhattacharyya, T., Pal, D. K., Chandran, P., Ray, S. K., Mandal, C. and Telpande, B., Soil carbon storage capacity as a tool to prioritize areas for carbon sequestration. Curr. Sci., 2008, 95, 482, 494.

18. Lal, R., Soil carbon sequestration in India. Climatic Change, 2004, 65, 277-296.

19. Aryal, J. P., Sapkota, T. B., Jat, M. L. and Bishnoi, D. K., Onfarm economic and environmental impact of zero-tillage wheat: a case of north-west India. Exp. Agric., 2015, 51, 1-16.

20. Ghimire, R., Adhikari, K. R., Chen, Z. S., Shah, S. C. and Dahal, K. R., Soil organic carbon sequestration as affected by tillage, crop residue, and nitrogen application in rice-wheat rotation system. Paddy Water Environ., 2012, 10, 95-102.

21. Bhattacharyya, P., Roy, K. S., Neogi, S., Adhya, T. K., Rao, K. S and Manna, M. C., Effects of rice straw and nitrogen fertilization on greenhouse gas emissions and carbon storage in tropical flooded soil planted with rice. Soil Till. Res., 2012, 124, 119-130.

22. Gathala, M. et al., Optimizing intensive cereal-based cropping systems addressing current and future drivers of agricultural change in the northwestern Indo-Gangetic Plains of India. Agric. Ecosyst. Environ., 2013, 177, 85-97.

23. Anon., Soils of Bihar-the properties and classification. Dr Rajendra Prasad Central Agricultural University, Pusa, Samastipur, Bihar, 1986.

24. Mandal, B., Bandyopadhyay, P. K., Kundu, M. and Choudhury, S. G., Potential of double-cropped rice ecology to conserve organic carbon under subtropical climate. Global Change Biol., 2008, 14, 2139-2151.

25. Jackson, M. L., Soil Chemical Analysis, Prentice Hall, New Delhi, 1973.

26. Walkley, A. and Black, I. A., An estimation of the degtjareff method for determining soil organic matter and a proposed modification of the chromic acid titration method. Soil Sci., 1934, 34, 29-38.

27. Bhattacharyya, T. et al., Walkley-Black recovery factor to reassess soil organic matter: Indo-Gangetic Plains and black soil region of India case studies. Commun. Soil Sci. Plant Anal., 2015, 46, 2628-2648.

28. Subbiah, B. V. and Asija, G. L., A rapid procedure for the determination of available nitrogen in soils. Curr. Sci., 1956, 25, 259260.

29. Lindsay, W. L. and Norvell, W. A., Development of a DTPA soil test for zinc, iron, manganese, and copper. Soil Sci. Soc. Am. J., 1978, 42, 421-428.

30. Casida, J. E., Klein, D. A. and Santoro, T., Soil dehydrogenase activity. Soil Sci., 1964, 98, 371-376.
31. Grossman, R. B., Harrms, D. S., Kinngsbury, D. F., Shaw, R. K. and Jenkins, A. B., Assessment of soil organic carbon using the US Soil Survey. In Assessment Methods for Soil Carbon (eds Lal, R. et al.), CRC Press, Boca Raton, FL, USA, 2001, pp. 87-102.

32. Penman, J. et al. (eds), Intergovernmental Panel on Climate Change (IPCC). Good Practice Guidance for Land Use, Land-use Change and Forestry, Institute for Global Environmental Strategies, Japan, 2003; www.ipcc-nggip.iges.or.jp/public/gpglulucf/ gpglulucf_contents.html

33. Jobbágy, E. G. and Jackson, R. B., The vertical distribution of soil organic carbon and its relation to climate and vegetation. Ecol. Appl., 2000, 10, 423-436.

34. McDonald, A. J., Riha, S. J., Duxbury, J. M., Steenhuis, T. S. and Lauren, J. G., Soil physical responses to novel rice cultural practices in the rice-wheat system: comparative evidence from a swelling soil in Nepal. Soil Till. Res., 2006, 86, 163-175.

35. Sabine, Z., Sabine, G., Claus-Felix, T., Karin, H. and Wilhelm, C., Effects of reduced tillage on crop yield, plant available nutrients and soil organic matter in a 12-year long-term trial under organic management. Sustainability, 2013, 5, 3876-3894.

36. Zentner, R. P., Lafond, G. P., Derksen, D. A., Nagy, C. N., Wall, D. D. and May, W. E., Effects of tillage method and crop rotations on non-renewable energy use efficiency for a thin Black Chernozem in the Canadian Prairies. Soil Till. Res., 2004, 77, 125-136.

37. Weber, M. A., Mielniczuk, J. and Tornquist, C. G., Changes in soil organic carbon and nitrogen stocks in long-term experiments in southern Brazil simulated with century 4.5. Rev. Bras. Ciên. Solo, 2016, 40; http://dx.doi.org/10.1590/18069657rbcs20151115.

38. Davidson, A. Eric and Ackerman, Else, L., Changes in soil carbon inventories following cultivation of previously untilled soils. Biogeochemistry, 1993, 20, 161-193.

39. Lal, R., Residue management, conservation tillage, and soil restoration for mitigating greenhouse effect by $\mathrm{CO}_{2}$ enrichment. Soil Till. Res., 1997, 43, 81-107.

40. Sakin, E., Relationships between carbon, nitrogen stocks and texture of the Harran plain soils in south eastern Turkey. Bulg. $J$. Agric. Sci., 2012, 18, 626-634.

41. Sharma, R. P., Singh, M. and Sharma, J. P., Correlation studies on micronutrients vis-à-vis soil properties in some soils of Nagaur district in semi-arid region of Rajasthan. J. Indian Soc. Soil Sci., 2003, 51, 522-527.

42. Kumar, M. and Babel, A. L., Available micronutrient status and their relationship with soil properties of Jhunjhunu Tehsil, District Jhunjhunu, Rajasthan, India. J. Agric. Sci., 2011, 3, 97-106.

43. Sharma, Y. M., Jatav, R. C., Sharma, G. D. and Thakur, R., Status of micronutrients in mixed red and black soils of Rewa district of Madhya Pradesh, India. Asian J. Chem., 2013, 25, 3109-3112.

44. Meena, R. S. and Mathur, A. K., Distribution of micronutrients in Soil of Garhi Tehsil, Banswara District of Rajasthan, India. Int. J. Curr. Microbiol. Appl. Sci., 2017, 6, 3765-3772.

45. Adak, T. Singh, A., Kumar, K., Shukla, S. K., Singh, A. and Singh V. K., Soil organic carbon, dehydrogenase activity, nutrient availability and leaf nutrient content as affected by organic and inorganic source of nutrient in mango orchard soil. J. Soil Sci. Plant Nutr., 2014, 14, 394-406.

Received 10 October 2019; revised accepted 8 January 2021

doi: $10.18520 / \mathrm{cs} / \mathrm{v} 120 / \mathrm{i} 8 / 1334-1341$ 